\title{
EAST SLAVIC PARALLELS AND SINGULARITIES IN THE TRILINGUAL AXIOLOGICAL DICTIONARY OF PROVERBS ${ }^{1}$
}

\author{
Valery M. Mokienko \\ St. Petersburg University, Saint Petersburg, Russia \\ Tatiana G. Nikitina \\ Pskov State University, Pskov, Russia
}

\begin{abstract}
The article presents an innovative concept of a comparative dictionary that allows to reflect the objective analysis of the similar and different aspects in axiologically oriented paremiological systems of the East Slavic languages. Comprehensive collected dictionaries that include tens of thousands of Russian, Ukrainian and Belarusian proverbs, found in handwritten and printed collections of the last four centuries, have been used for this research. The expediency of including not only paroemias denotatively correlated with basic universal values, but also other proverbs associated with the category of evaluation in the object of the dictionary linguo-axiological description is justified. Based on the material of one of these axiological dyads - fast / slow - the features of structuring the thematic headings of the axiological comparative dictionary of East Slavic proverbs are shown. The system of parameterization of the material based on the results of its structural-semantic, historical-etymological and comparative linguo-axiological analysis is viewed through the example of macro-entries. Based on the material of the considered paroemias, it was found out that the national distinguishing characteristic of East Slavic paroemias consists not in their axiological content but in the form of its expression. The prospects of using the proposed model of the dictionary description of paroemias and phraseological units in the practice of axiological lexicography are emphasized.

Key words: East Slavic languages, lexicography, linguoaxiology, proverb, paremiological parallels, ethnocultural specificity of paremia, comparative axiological dictionary.

Citation. Mokienko V.M., Nikitina T.G. East Slavic Parallels and Singularities in the Trilingual Axiological Dictionary of Proverbs. Vestnik Volgogradskogo gosudarstvennogo universiteta. Seriya 2. Yazykoznanie [Science Journal of Volgograd State University. Linguistics], 2021, vol. 20, no. 4, pp. 126-136. (in Russian). DOI: https:// doi.org/10.15688/jvolsu2.2021.4.10
\end{abstract}

\section{ВОСТОЧНОСЛАВЯНСКИЕ ПАРАЛЛЕЛИ И УНИКАЛИИ В ТРЕХЬЯЗЫЧНОМ АКСИОЛОГИЧЕСКОМ СЛОВАРЕ ПОСЛОВИЦ ${ }^{1}$}

\author{
Валерий Михайлович Мокиенко \\ Санкт-Петербургский государственный университет, г. Санкт-Петербург, Россия
}

Татьяна Геннадьевна Никитина

Псковский государственный университет, г. Псков, Россия

Аннотация. В статье представлена инновационная концепция сопоставительного словаря, позволяющего отразить объективную диагностику общего и различного в аксиологически ориентированных паремиологических системах восточнославянских языков. Исследование выполнено на материале фундаментальных сводных словарей, включающих десятки тысяч русских, украинских и белорусских пословиц, зафикси- 
рованных в рукописных сборниках и печатных изданиях последних четырех столетий. Обоснована целесообразность включения в объект словарного лингвоаксиологического описания не только паремий, денотативно соотнесенных с базовыми общечеловеческими ценностями, но и других пословиц, связанных с категорией оценки. На примере одной из таких признаковых аксиологических диад - БЫСТРО - МЕДЛЕННО - показаны особенности структурирования тематических рубрик аксиологического сопоставительного словаря восточнославянских пословиц. Охарактеризована система параметризации материала, базирующаяся на результатах его структурно-семантического, историко-этимологического и сопоставительного лингвоаксиологического анализа. В результате анализа рассмотренных в сопоставительном плане паремий сделаны выводы о национальной специфике восточнославянских паремий, которая заключается не в их аксиологическом содержании, а в форме выражения этого содержания. Подчеркивается перспективность использования предлагаемой модели сопоставительного словарного описания паремий и фразеологизмов в практике аксиологической лексикографии.

Ключевые слова: восточнославянские языки, лексикография, лингвоаксиология, пословица, паремиологические параллели, этнокультурная специфика паремий, сопоставительный аксиологический словарь.

Цитирование. Мокиенко В. М., Никитина Т. Г. Восточнославянские параллели и уникалии в трехъязычном аксиологическом словаре пословиц // Вестник Волгоградского государственного университета. Серия 2, Языкознание. -2021. - Т. 20, № 4. - C. 126-136. - DOI: https://doi.org/10.15688/jvolsu2.2021.4.10

\section{Введение}

Сравнительно-историческое и сопоставительное исследование русских, украинских и белорусских языковых единиц не только не утрачивает актуальности в сложной современной геополитической обстановке, но и все активнее развивается в новых направлениях, в том числе лингвоаксиологическом, в рамках которого выявляется ценностная ориентация и оценочная семантика восточнославянских пословиц [Ломакина, Мокиенко, 2018; 2019; Марфина, 2018]. Говоря о пословицах, мы будем иметь в виду логически законченные народные изречения афористического характера, используемые в переносном или прямом и переносном смыслах, а также «имеющие только буквальный план» устойчивые выражения, которые квалифицируются как поговорки [Жуков, 1991, с. 11], но традиционно описываются в паремиологических словарях вместе с пословицами. Для обозначения пословиц как одного из видов паремий [Пермяков, 1988, c. 80] в статье будет использоваться и термин «паремия».

Как показал анализ двуязычных и многоязычных паремиологических словарей (Иванов, Мокиенко; Котова; Чусь), результаты лингвоаксиологических исследований восточнославянских пословиц пока не находят должного отражения в лексикографической практике: как правило, межъязыковые паремиологические параллели репрезентируются без какой-либо интерпретации их оценочной семантики, а большинство безэквивалентных паремий, среди которых немало ценностно ориентированных единиц, не включается составителями в объект описания. В такой ситуации остается нераскрытым соотношение общего и этноспецифического в аккумулируемых пословицами аксиологических установках и социокультурных стереотипах восточных славян, в их ассоциативно-образном восприятии действительности и языковом воплощении оценочных реакций.

Объективное этнолингвистическое и лингвоаксиологическое словарное описание восточнославянского паремиологического пространства позволит еще раз убедительно продемонстрировать роль языкового единства восточных славян в становлении их национальных языков (в частности, паремиологических фондов), что особенно важно в условиях противостояния курсу на языковую дезинтеграцию, провозглашенному политиками некоторых восточнославянских стран и поддерживаемому псевдонаучными лингвистическими и культурологическими теориями.

Лексикографически представить в лингвоаксиологическом ракурсе паремиологическую систему восточнославянских языков с максимальной полнотой и объективностью такую цель ставят перед собой авторы сопоставительного словаря «Пословицы восточных славян», который разрабатывается в рамках проекта «Мир восточных славян в паремиологической интерпретации: аксиологические доминанты и их лингвокультурографичес- 
кая репрезентация», реализуемого членами фразеологического семинара профессора B.M. Мокиенко в Санкт-Петербургском государственном университете (СПбГУ). Цель данной статьи - описать инновационную концепцию проектируемого словаря.

\section{Материал и методы исследования}

Источником материала для исследования послужила картотека фразеологического семинара СПбГУ, паремиологический раздел которой включает более 100 тысяч русских пословиц, извлеченных из паремиологических сборников и словарей XVII-XXI вв., толковых и диалектных словарей (всего более 380 источников), а также паремий, записанных членами семинара в ходе диалектологических экспедиций и полевых исследований городской речи. Частично материал картотеки использован в «Большом словаре русских пословиц» В.М. Мокиенко, Т.Г. Никитиной и Е.К. Николаевой (МНН), объем которого составляет 70 тыс. единиц. Белорусские и украинские паремии отбирались из сопоставимых с этим словарем по охвату материала собраний М.Я. Грынблата «Прыказкі і прымаўкі» (Гр.) и М.М. Пазяка «Прислів'я та приказки» (Паз.).

В ходе работы над проектом использовались общетеоретические методы: анализ и синтез, формализация, обобщение; методы интерпретации и верификации данных: типологизация, моделирование, концептуализация, обеспечивающие точность и научную достоверность результатов исследования.

Этапу лексикографирования материала предшествовало масштабное сопоставительное исследование паремий трех языков в семантическом и культурно-историческом плане. Методы историко-этимологического анализа паремий и компонентного анализа их смысловой структуры на основе данных словарей, методика аппликации словарных статей и сопоставительного лингвоаксиологического анализа позволили максимально полно выявить трехъязычные и двуязычные паремиологические параллели, а также этноспецифические пословицы. Для разграничения паремиологических вариантов и синонимов в ходе сопоставительного анализа применялся метод структурно-семантического моделирования.

Параллельно с сопоставительным исследованием пословиц трех восточнославянских языков был проанализирован лингвоаксиологический потенциал паремиологических словарей разных типов. Особенно ценны в этом плане тематические паремиографические сборники. По мнению Л.К. Байрамовой, «закодированные в сознании и культуре социумов» и отражаемые пословицами ценности и антиценности могут быть представлены в 10 диадах [Байрамова, 2014, с. 10]. Они тематически организуют корпус первого в отечественной лексикографии аксиологического фразеологического словаря (автор широко понимает фразеологию, включая в объект описания в основном пословицы) (Байрамова) и объединяют паремии, репрезентирующие ценности и антиценности: витальные (Жизнь - Смерть, Здоровье - Болезнь), социально-утилитарные (Труд - Безделье), интеллектуально-когнитивные ( $V_{\mathcal{M}}-$ Глупость) и т. п.

Согласно нашей концепции, ценность паремиологического словаря как лингвоаксиологического источника значительно возрастет, если наряду с этими базовыми ценностями культуры в пословичном отображении будут представлены и оппозиции признаков, определяющих вектор оценки (сенсорной, утилитарной, нормативной и др. [Арутюнова, 1988, с. 75-76]) самых разных объектов и явлений окружающего мира. К таким маркерам оценивания действительности Т.В. Григорьева относит пространственные, цветовые, размерные и другие оппозиции признаков ('верх - низ', 'черный белый', ‘большой - маленький' и т. п.), включенные в «мировоззренческую сетку координат, которая помогает человеку ориентироваться в многообразном окружающем мире» [Григорьева, 2015, с. 91].

Возможности словарной репрезентации аксиологической наполненности таких оппозиций будут описаны ниже на материале рубрики БЫСТРО - МЕДЛЕННО, разработанной для трехъязычного аксиологического словаря. Как показал лингвокультурологический анализ отобранных для этой рубрики паремий, они отражают народные представления вос- 
точных славян о скорости как оценочном временно́м параметре совершения действий и протекания процессов. Обобщенный оценочный смысл таких паремий может быть передан в форме аксиологем - пропозиционально организованных формулировок. Л.К. Байрамова называет такие формулировки «моралью» и впервые использует их в формате аксиологического словаря, регистрируя эту лексикографическую технологию как заявку на изобретение [Байрамова, 2014, с. 10].

Концепция использования аксиологем в сопоставительном паремиологическом словаре апробирована нами на русско-венгерском материале [Никитина, 2016]. В новом проекте эта лексикографическая технология будет реализована на материале трех языков, при этом будет применен экспериментальный прием макроструктурирования словаря - расположение материала по убыванию количества паремиологических параллелей, за счет чего будет показана продуктивность общих для восточных славян пословичных аксиологем и этнокультурная специфика паремиологических уникалий.

\section{Результаты и обсуждение}

\section{Аксиология скорости \\ в пословицах восточных славян: лексикографический блок БЫСТРО}

Восточнославянские пословицы со скоростным семантическим компонентом 'быстро' в большинстве своем (73\% материала данного блока) отрицательно оценивают качество работы, выполненной наспех, в короткий срок; высокую скорость движения, не приводящую к сокращению времени в пути; поспешное, необдуманное принятие решений и т. п., что будет отражено в первом блоке рубрики БЫСТРО - МЕДЛЕННО, где, согласно нашей лексикографической концепции, знак (-) указывает на негативную оценочность паремий блока, знаки $(=)$ и $(\sim, \sim)$ внутри макростатей отражают полную и частичную (с разной степенью сходства) межъязыковую эквивалентность паремий, а знаком (\#) помечены безэквивалентные аксиологемы и этноспефицические паремиологические образы:

\section{БЫСТРО}

$(-)$

1. 'Быстро выполняемая работа не приводит к качественному результату':

- Быстро только кошки родятся, да и то слепые (Сок., с. 69). = Скора каты робяцца*, ды сляпыя родзяцца. Бел. (Гр., т. 1, с. 180). Сабакі хутка* робяцца, да доўга сляпыя. Бел. (Гр., т. 1, с. 180). Укр. Що швидко* робиться, те сліпе родиться (Паз., т. 1, с. 292).

- Скоро не бывает споро ( $\mathrm{MHH}$, c. 814). = Што скора, то і не спора. Бел. (Гр., т. 1, с. 179). Що швидко, то бридко*. Укр. (Паз., т. 2, с. 281).

\# На скорую ручку - комком да в кучку (MHH, с. 776).

\# Швидка робота погана*. Укр. (Паз., т. 1, с. 291).

Ср.: БЫСТРО (+) 4. (Так в конце лексикографического описания паремий, воплощающих данную аксиологему, дается отсылка к противоположной по аксиологическому вектору макростатье под заголовком 'Высокая скорость выполняемой работы обеспечивает желаемый результат', таким образом раскрывается амбивалентность оценки народным сознанием скоростных параметров совершаемого действия. Эти отсылки являются перекрестными, как и отсылки, связывающие оппозитивные блоки.)

(Помеченные звездочкой компоненты белорусских и украинских паремий, которые могут быть непонятны русскоязычному читателю, получат толкования в «Приложении» к словарю: укр. *бридко - безобразно; поганий - плохой; швидко - быстро; бел. *робяицุа (рабіциа) - делаться; хутка - быстро.)

2. 'Быстро выполняя работу, совершая какое-л. действие, можно оконфузиться, стать объектом насмешки':

- Скорый поспех людям на смех (Сок., с. 72). = Скоры паспех людзям на смех. Бел. (Гр., т. 1, с. 179). = Скорий поспіх - людям посміх. Укр. (Паз., т. 1, c. 300). 3 вялікага паспеху наробіш смеху. Бел. (Гр., т. 1, с. 179). Ад спеху не нарабіць бы смеху. Бел. (Гр., т. 1, с. 179).

- Поспешишь - людей насмешишь (MHН, с. 504). = Паспяшыць (спяшыць) людзей насмяшыць. Бел. (Гр., т. 1, с. 179). 
Хто спішить, той людей смішить. Укр. (Паз., т. 1, с. 300).

- Делано наспех - сделано на смех (MHН, с. 835). Рублена наспех і зроблена насмех. Бел. (Гр., т. 1, с. 180).

\# Що спішно, то смішно. Укр. (Паз., т. 1, с. 300).

Именно две эти аксиологемы особенно широко представлены трехъязычными и двуязычными восточнославянскими паремиологическими параллелями, которые приводятся здесь без учета их многочисленных лексических вариантов, что не противоречит нашей цели - показать важнейшие черты «аксиологического портрета» скорости в формате сопоставительного словаря пословиц.

Общей для трех восточнославянских народов является и пословичная идея 'работу, сделанную наспех, придется переделывать', открывающая макростатью 3. Украинцы и белорусы сопоставляют при этом временные параметры двух трудовых процессов: Наскоро сделать - передельвать (МНH, с. 244). Хутка робіць, але перарабляе доўга. Бел. (Гр., т. 2, с. 289). = Швидко робить, та переробляє довго. Укр. (Паз., т. 1, с. 291).

'Быстро совершаемое действие, быстро выполняемая работа забирает много сил' - это основание негативной оценки скорости, вынесенное в заголовок макростатьи 4 рассматриваемого блока, находим в русскоукраинской пословичной параллели с небольшими лексическими расхождениями: Кто быстро идет, тот скоро устает (Сок., с. 70). Хто скоро біжить, той скоро $i$ стане. Укр. (Паз., т. 2, с. 271). Образы русских пословиц, представленных под знаком (\#), усиливают эффект предостережения: Горячий конь скоро надорвется (Сок., с. 523); Резвый (ретивый) надсадится, горячий надорвется (Сок., с. 71).

Еще более убедительны пословицы, объединенные под аксиологемой 5 'Действуя быстро, можно попасть в беду, подвергнуться наказанию', которая представлена исключительно этноспецифическим материалом: рус. Кто резов, того больше бьют (МНН, с. 751); Быстрому коню - глубокая яма (MHН, с. 429); Быстрая вошка попадает (попадёт) на гребешок (МНH, с. 159); Смелей живи - быстрей (скорей) повесят
(МНH, с. 350); укр. Чорт скорих бере (Паз., т. 3, c. 291).

Аксиологема 6 'Быстрое принятие решения приводит к нежелательным последствиям' конкретизируется в трехъязычной паремиологической параллели на актуальном примере неудачной женитьбы. Общий лексический фонд обеспечивает единство ритмической организации паремий за счет рифмопары руку - муку: Женился на скорую руку да на долгую муку $(\mathrm{MHH}$, с. 774). = Женився на скору руку та на довгу муку. Укр. (Паз., т. 2, с. 68). = Жаніууся на скорую руку - на доўгую муку. Бел. (Гр., т. 2, с. 55).

Аксиологемы, связанные с высокой скоростью передвижения, также довольно конкретны (компонент ездить, ехать, гнать ограничивает употребление паремий дорожнотранспортными ситуациями, хотя возможно и использование их в обобщенном переносном смысле - для оценки других ситуаций проявления поспешности, чреватой последствиями, что при наличии достаточного количества подтверждающих контекстов позволит включить этот материал и в макростатью 5).

Здесь же на примере аксиологемы 7 'Движение с высокой скоростью приводит к несчастному случаю' покажем приоритетность традиционных паремий в порядке их расположения. За приведенным выше аксиологическим заголовком следует белорусско-украинская параллель Прытка едзеш - голаву звернеш. Бел. (Гр., т. 1, с. 278). = Прудко їзиш (поїдеш) - голову звернеш. Укр. (Паз., т. 1 , с. 300$)$ и только затем - современная паремиологическая трансформация, зафиксированная в России и на Украине: Быстро поедешь - тихо повезут (понесут) (Сок., с. 69, 379). = Швидко їдеш - тихо понесуть. Укр. (Паз., т. 1, с. 244). < Трансф. Тише едешьдальше будешь.

Таким образом (под знаком $(<))$ в словаре наряду с другими этимологизирующими и культурологическими комментариями будут показаны исходные паремии при трансформах, утративших окказиональность и фиксируемых словарями в одном ряду с каноническими пословицами. В отличие от этих новых кодифицированных паремий в словарь не включаются индивидуально авторские трансформации, типа: Тише едешь - гаишники без навара; 
Tише едешь - больше мата (в пробке); Tише едешь - ты чайник (неопытный водитель) и т. п.

Этноспецифические аксиологемы-заголовки макростатей будут маркироваться в словаре, подобно отдельным безэквивалентным паремиям, знаком (\#), как, например, в следующем случае, завершающем аксиологическое представление высокой скорости передвижения или выполнения каких-либо других действий:

\# 8. 'Быстрое движение не гарантирует скорого прибытия к месту назначения' / 'Поспешное выполнение работы не гарантирует скорого ее завершения':

\# Шибко (спешно, резво) ехать не скоро доехать (MHH, с. 331).

\# Которые поспешали, те дома не ночевали (МНH, с. 704).

Говоря об этноспецифических аксиологемах, необходимо подчеркнуть определенную условность их выделения, соглашаясь с точкой зрения В. Хлебды [Хлебда, 2008, с. 96] о том, что все пословичные идеи интернациональны, но их реализация в каких-то языках, возможно, пока не обнаружена исследователями. Таким образом, маркировка аксиологемы знаком (\#) указывает лишь на то, что утверждение об отсутствии параллелей при воплощении пословичной идеи основывается на материалах рассмотренных источников и актуально лишь для настоящего момента исследования.

Высокая скорость протекания процессов (природных, социальных, психических, физиологических) не столь широко представлена паремиями в аксиологическом аспекте. Их содержание сосредоточено в смысловом пространстве таких гедонических, материальноутилитарных, морально-этических, эстетические ценностей, как счастье и несчастье, богатство и бедность, добро и зло, красота и ее отсутствие, которые интерпретируются применительно к повседневной жизни простого человека и констатируют (с сожалением или иронией) преобладание в этой жизни антиценностного компонента данных оппозиций: 'Беда приходит быстро', 'Счастье быстро уходит', 'Деньги быстро уходят, расходуются', Добро быстро забывается', 'Красота быстро исчезает'. Макростатьи под этими заголовками и будут завершать лексикографический блок
БЫСТРО (-), представляя как полные белорусские и украинские эквиваленты русских пословиц Беда скоро ходит; Копейка круглая, без расчета быстро укатится; Добро скоро забывается, а худое в памяти сохраняется и др., так и паремии, воплощающие этноспецифические образы, например, у украинцев: счастье, скачущее от человека на быстром коне; женская красота, исчезающая так же быстро, как радуга (Паз., т. 2, с. 37; т. 3 , с. 173).

Порядок подачи частей $(+)$ или (-) в лексикографическом блоке определяется количеством материала, а значит, и важностью данной оценочной характеристики для носителя языка. На этот показатель мы ориентируемся и при расположении в словаре паремий, положительно и отрицательно оценивающих высокую скорость: І. БЫСТРО: Быстро (-); Быстро (+).

Русские паремии трех первых макростатей, расположенных под знаком $(+)$, имеют параллели в украинском языке и утверждают, что быстрота в еде - показатель высокой работоспособности: рус. Скорый едок-спорый работник (МНH, с. 326). = укр. Скорий до ïди, скорий $і$ до роботи (Паз., т. 1, с. 287); родители должны скорее выдавать дочерей замуж: рус. Девушка - не бережённый товар: скорей сбывай (МНН, с. 240). укр. Коня бистрого зараз сідлай, дівку молоденьку заміж видавай (Паз., т. 2, с. 73); быстро оказывать помощь нуждающимся - особенно ценно: рус. Вдвойне дает тот, кто дает быстро (Сок., с. 607). = Подвійно дає, хто скоро дає (Паз., т. 3, с. 78).

4. 'Быстрота действий обеспечивает желаемый результат' - эту мысль передают одна белорусская и немногочисленные русские пословицы, не образующие межъязыковых параллелей и противопоставленные в оценочном плане большому количеству паремий первой части блока, что и покажет соответствующая отсылка в конце макростатьи:

\# Быстрота и внезапность заменяют число (Сок., с. 307, 433).

\# Шустрый да быстрый выходят в министры (Сок., с. 266).

\# Чым хутчэй*, тым ляпей*. Бел. (Гр., т. 1, с. 180). (Бел. *хутчэй - быстрее; ляпейлучше.) 
Ср.: БЫСТРО (-) 1.

Взаимными отсылками будут соединены и макростатьи БЫСТРО (+) 5 и БЫСТPО (-) 6, фиксирующие диаметрально противоположную оценку поспешной, скорой женитьбы. Но если в общей отрицательной оценке этого факта восточные славяне единодушны, то по одному конкретному параметру выгоду здесь усматривают русские:

\# Когда жениться скорее, так в дом будет спорее (MHH, с. 290).

\# Жениться скорее - в дому прибыльнее (МНH, с. 292).

Тему быстрого сватовства в положительном осмыслении, но без указания мотивации развивают и размещенные в данной макростатье украинские этноспецифические паремии, в образной структуре которых просматриваются реалии культуры казачества:

\# 3 коня злізай та дівку чорнобриву сватай. Укр. (Паз., т. 2, с. 73).

\# Коня бистрого зараз сідлай, дівчину молодую скоро сватай. Укр. (Паз., т. 2, с. 73).

Ср.: БЫСТРО (-) 1.

Известную особенность русского характера отражает паремия Русский медленно запрягает, да быстро скачет (Сок., с. 71). Она открывает репрезентацию этноспецифической аксиологемы 'Быстрое эффективное действие оправдывает его долгую подготовку, откладывание', завершающей блок БЫСТРО в его положительно маркированной части, где также разместятся паремии: Долго запрягали, да быстро едем (Сок., с. 590), Долго думано, да скоро сделано (МНН, c. 310) - и передающая аксиологему в назидательном ключе паремия-совет Долго рассуждай, да скоро делай (ДП, т. 2, с. 65), противопоставленная большому количеству пословиц, рекомендующих человеку действовать без спешки, планомерно и размеренно, которые будут размещены в представляющем оппозитивный компонент «скоростной диады» лексикографическом блоке МЕДЛЕННО.

\section{Аксиология скорости \\ в пословицах восточных славян: лексикографический блок МЕДЛЕННО}

На материале, представляющем первую аксиологему блока МЕДЛЕННО (+), покажем возможность лексикографического отображения своеобразной «конверсивно-антонимической» соотнесенности паремий (например, Скоро не бьвает споро. - Хоть не скоро, да cnopo), когда взаимодополняющая оценка оппозиционных скоростных параметров одного и того же объекта отражает единую аксиологическую установку говорящего. Ее комплексная репрезентация в словаре осуществляется посредством отсылки «См. также», как в приводимом ниже случае:

\section{МЕДЛЕННО}

$(+)$

1. 'Медленно выполняемая работа дает качественный результат':

- Хоть (Хотя) не скоро (нескоро), да здорово (ДП, т. 2 , с. 60). = Хоць не скора, да здарова. Бел. (Гр., т. 2, с. 212). = Укр. Хоч не скоро, та здорово (Паз., т. 1, с. 300).

См. также: БЫСТРО (-) 1.

По данной отсылке пользователь и найдет второй компонент комплексной оценки скоростных параметров действия: Скоро не бывает споро.

В макростатье 2 такая отсылка соединит общую для восточных славян положительную паремиологическую оценку спокойного, неторопливого передвижения или осуществления какой-л. деятельности (при употреблении пословицы в переносном смысле): Tuше едешь - дальше будешь (ДП, т. 2, с. 61), Tихше їдеш - далі будеш (станеш) Укр. (Паз., т. 1, с. 244), Памаленьку едзем, а далей станем. Бел. (Гр., т. 1, с. 278) - и противоположную оценку высокой скорости передвижения, представленную трехъязычными паремиологическими параллелями: См. также БЫСТPO (-) 5, 7, 8 .

Полными русско-украинско-белорусскими пословичными эквивалентами представлена и следующая по порядку расположения в словаре аксиологема, сопоставляющая и противопоставляющая дело и его речевое воплощение, причем большая вариативность свойственна здесь белорусским и украинским паремиям, проявляющим образный параллелизм, отраженный во второй микростатье:

3. 'Дело делается медленнее, чем может быть представлен его результат':

- Скоро сказка сказывается, да не скоро дело делается (ДП, т. 2, с. 63; Сок., с. 72, 
164). = Скора казка кажацца, ды не скора дзела дзелаецца. Бел. (Гр., т. 1, с. 181). = Скоро казка мовиться, та не скоро діло робиться. Укр. (Паз., т. 1, с. 295).

- Скоро говорится, [да] не скоро делается (ДП, т. 1, с. 318). = Скора гаворыцца, да не скора робіцца. Бел. (Гр., т. 1, с. 180$)$. = Не так швидко робиться, як мовиться. Укр. (Паз., т. 1, с. 283). Скора песня пяецца, ды не скора складаецца. Бел. (Гр., т. 2, с. 192) = Швидко пісня співається, та не швидко складається. Укр. (Паз., т. 3, с. 48).

Отсюда - одна из пословичных рекомендаций, представленная русско-белорусской параллелью Не спеши языком, торопись делом (ДП, т. 1, с. 318). = Не спяшайся языком, а спяшайся дзелам. Бел. (Гр., т. 2, c. 279), которая размещается при аксиологеме 4 'Не следует торопиться с какими-л. заявлениями, пока дело не сделано'.

По модели «Не следует спешить в каком случае, почему, зачем и т. п.» будут конструироваться заголовки и других макростатей, объединяющих паремии, регулятивная функция которых, в отличие от других оценочных паремий, эксплицируется за счет форм инфинитива и прежде всего негативных форм глаголов со скоростной семантикой.

Наиболее широко представлена восточнославянскими паремиологическими параллелями аксиологема 5 'Не следует спешить (как правило, в опасном, ответственном деле), опережая кого-л. более опытного, старшего' Пространственный компонент образной структуры паремий получает как общий для трех языков способ выражения (пекло), так и ареальные русско-белорусские (петля, виселица) или этноспецифические варианты: вода (рус.), женитьба (бел.):

- Вперед (наперед) батьки в пекло не суйся (не лезь) $(\mathrm{MHH}$, с. 37$)$. = Не сунься (не спіши, не скачи, не хапайся) поперед батька в пекло. Укр. (Паз., т. 2, с. 106). = Не спяшайся ўпярод бацькі ў пекла. Бел. (Гр., т. 2, с. 463).

- Наперед батьки в петлю не суйся (не лезь) $(\mathrm{MHH}$, с. 37). = Не хапайся (не спяшайся, не кідайсь) упярод бацькі на шыбеніцу*. Бел. (Гр., т. 2, c. 464). (Бел. *щылбеніца - виселица.)
\# Вперед батьки не лезь в воду (МНH, c. 37). < Контаминация: Вперед батьки в пекло не лезь и Не зная броду, не суйся в воду.

\# Не спяшайся ўпярод бацька жаніцца. Бел. (Гр., т. 2, с. 25).

Мотив виселицы культивируется белорусами и в паремиях, иронически репрезентирующих аксиологему 6 'Не спеши, опережая события': Не спяшы (не спятайся) на шыбеніиу, яшчэ навісішся; Не спяшы на шыбеніиу, nаспееш яшчэ (Гр., т. 2, с. 464). Ср. у русских: Не спеши умирать, ещё належишься (MHH, c. 864).

Не следовать примеру тех, кто спешит, прагматическая установка, имплицитно передаваемая этноспецифическими русскими пословицами: Быстро только лодыри кашу едят (Сок., с. 69), Быстро только кошка мылшь ловит (Сок., с. 69), Скоро блох ловят (ДП, т. 2, с. 62). Хотя здесь зафиксирована и русско-белорусская параллель: Поспешность (спешка) нужна при ловле блох (Сок., с. 71). Шпаркасиь * хараша блох лавіщь (Гр., т. 1, c. 180). (Бел. *Шпаркасиь - поспешность.)

Русско-белорусские паремиологические параллели обосновывают имплицитно выраженный совет не спешить: неторопливому человеку помогает Бог и силы природы: Резвый сам набежит (натечет), а смирного Бог нанесет (ДП, т. 1, с. 197). = Скоры сам набяжыць, а на иіхага бог нанясе (Гр., т. 2, с. 306); Быстрый сам добежит, а тихого вода донесёт (МНH, с. 129). На иіхага* вецер навее, а рэзвы $і$ сам набяжыць (Гр., т. 2, с. 306). (Бел. *иіхага (uіхі) - тихий, спокойный.)

Убедительны русские пословицы с уникальным логическим обоснованием рекомендации не спешить: рус. Зачем спешить можно и опоздать (Сок., с. 414); Не торопись: когда смелешь, тогда и съешь (ДП, т. 2, с. 62); Кто не спешит, тот меньше грешит (МНH, с. 864). Украинские и белорусские паремии с этой целью воздействуют на адресата за счет ярких образов, представляющих последствия спешки: бел. Не спяшы, каза, у лес: усе вауккі* твае будуиь (Гр., т. 1, c. 196). (Бел. *вауккі - волки); укр. Поволі*, Гриию (Іване), бо на (у) корито впадеш (Паз., т. 2, с. 207, 208); Помалу*, Хомо, Миколу звалиш (Паз., т. 2, с. с. 216); Помалень- 
ку, бо спинку зломиш (Паз., т. 2, с. 256). (Укр. *nоволі, помалу - помедленнее.)

В материале, отобранном для аксиологического словаря «Пословицы восточных славян» из основных паремиографических источников русского, белорусского и украинского языков, не оказалось паремий, негативно оценивающих невысокую скорость действий и процессов, что неудивительно: народная аксиология связывает этот признак с тщательностью, аккуратностью, продуманностью действий. Таким образом, в лексикографическом блоке МЕДЛЕННО будет отсутствовать часть под знаком (-), но завершать рубрику БЫСТРО - МЕДЛЕННО будет третий блок, макростатьи которого представляют негативную оценку обоих компонентов семантической оппозиции человеком, осознающим бесполезность прилагаемых усилий и безысходность своего положения:

III. БЫСТРО (-) / МЕДЛЕННО (-)

1. 'Независимо от скорости выполняемых действий, исход дела будет одинаково печальным':

- Иди скоро - нагонишь горе; иди тихо - тебя нагонит лихо (ДП, т. 1, с. 119). = Іди скоро - наженеш горе, іди тихо тебе нажене лихо. Укр. (Паз., т. 3. С. 157). $\sim$ Еду ціха - са мной ліха, еду скора - са мной гора. Бел. (Гр., т. 1, с. 453).

\# 2. 'Скорость выполнения работы (высокая или невысокая) не обеспечивает хорошего результата':

\# Як дій* швидко, то бридко, дій тихо, то (і так) лихо. Укр. (Паз., т. 2, с. 426). (Укр. *дій (діяти) - действовать, делать что-л.)

\section{Выводы}

Таким образом, предлагаемая система сопоставительной словарной репрезентации пословиц дает возможность наглядно представить паремиологическую интерпретацию окружающего мира восточными славянами во всех сходствах и различиях их ценностных приоритетов и этнокультурных стереотипов. Общность и специфика этих параметров может быть показана в словаре на уровне отдельных паремий (в микростатьях, отражающих межъязыковые параллели и уникальные пословицы), на уровне аксиологем, репрезен- тируемых материалом макростатей в рамках каждого из оппозитивных оценочных блоков, и на уровне этих блоков в дихотомически организованной рубрике. Использование данной модели лексикографирования материала повышает ценность паремиологического словаря как лингвоаксиологического источника, что позволяет говорить о целесообразности широкого внедрения модели в практику сопоставительной аксиологической лексикографии.

Представленные в таком лексикографическом формате результаты лингвоаксиологического анализа восточнославянских паремий со скоростным семантическим компонентом свидетельствуют об общности вектора оценочной интерпретации русскими, украинцами и белорусами скоростных параметров выполняемой работы, передвижения в пространстве, протекания природных процессов и наличии в трех паремиологических системах определенного количества этноспецифических образных средств выражения оценки. Таким образом, в очередной раз подтверждается вывод, к которому приходят многие исследователи восточнославянских паремий: национальная специфика языковых единиц этой категории проявляется на уровне формы, а не содержания, отражающего, как правило, универсальные паремиологические идеи и дидактические рекомендации.

\section{ПРИМЕЧАНИЕ}

${ }^{1}$ Исследование выполнено при финансовой поддержке Российского научного фонда, проект № 20-18-00091 «Мир восточных славян в паремиологической интерпретации: аксиологические доминанты и их лингвокультурографическая репрезентация», реализуемый в Санкт-Петербургском государственном университете.

The study is funded by the Russian Science Foundation, project No. 20-18-00091 «The world of the Eastern Slavs in a paremiological interpretation: axiological dominants and their linguistic and cultural representation», implemented at St. Petersburg State University.

\section{СПИСОК ЛИТЕРАТУРЫ}

Арутюнова Н. Д., 1988. Типы языковых значений : Оценка. Событие. Факт. М. : Наука. 338 с. 
Байрамова Л. К., 2014. Пословицы в «Аксиологическом фразеологическом словаре русского языка: словаре ценностей и антиценностей» // Вестник Новгородского государственного университета. № 77. С. 10-12.

Григорьева Т. В., 2015. Аксиологические особенности оппозиции 'сладкий - горький' в русском языке // Вестник Вятского государственного гуманитарного университета. № 8. С. 87-93.

Жуков В. П., 1991. Предисловие. О словаре пословиц и поговорок // Жуков В. П. Словарь русских пословиц и поговорок. М. : Рус. яз. С. 9-21.

Ломакина О. В., Мокиенко В. М., 2018. Ценностные константы русинской паремиологии (на фоне украинского и русского языков) // Русин. Т. 54, вып. 4. С. 303-317. DOI: 10.17223/18572685/54/18.

Ломакина О. В., Мокиенко В. М., 2019. Концептуальная дихотомия «Бог» - «Дьявол» в русинской фразеологии и паремиологии (на славянском фоне) // Вестник Томского государственного университета. № 447. С. 55-62. DOI: $10.17223 / 15617793 / 447 / 7$

Марфина Ж. В., 2018. Ценностно-аксиологическая реализация микроконцептов муж, жена в украинской и русской паремийных картинах мира // Вестник Костромского государственного университета. Т. 24, № 1. С. 90-94.

Никитина Т. Г., 2016. Сопоставительный словарь пословиц и поговорок как лингвокультурологический и лингвокраеведческий источник // Вестник Псковского государственного университета. Серия: Социально-гуманитарные науки. № 4. С. 142-149.

Пермяков Г. Л., 1988. Основы структурной паремиологии. М. : Наука. 235 с.

Хлебда В., 2008. О чем думает русский индюк, или Об эквивалентах пословиц в двуязычном словape // Przegląd Rusycystyczny. № 4 (124). C. $90-104$.

\section{СЛОВАРИ}

Байрамова - Байрамова Л. К. Аксиологический фразеологический словарь русского языка: словарь ценностей и антиценностей. Казань : Центр инновац. технологий, 2011.359 с.

Гр. - Прыказкі і прымаўкі : у 2 кн. / склад. М. Я. Грынблат. Мінск : Навука і тэхніка, 1976. 2 кн.

ДП - Даль В. И. Пословицы русского народа : в 2 т. М. : Худож. лит., 1984. 2 т.

Иванов, Мокиенко - Иванов Е. Е., Мокиенко В. М. Русско-белорусский паремиологический словарь. Могилев : Изд-во МГУ им. А.А. Кулешова, 2007.242 c.
Котова - Котова М. Ю. Русско-славянский словарь пословиц с английскими соответствиями. СПб. : Изд-во СПбГУ, 2000.360 с.

МHН - Мокиенко В. М., Никитина Т. Г., Николаева Е. К. Большой словарь русских пословиц. М. : Олма Медиа Групп, 2010. 1024 с.

Паз. - Прислів'я та приказки : у 4 т. / упорядник М. М. Пазяк. Київ : Наукова думка, 1989-2001. T. 1. 1989. 479 c. ; T. 2. 1990.524 c.; T. 3. 1991. 440 c. ; T. 4.2001 .392 c.

Сок. - Соколова М. И. Народная мудрость. Пословицы и поговорки. Новосибирск : Офсет, 2009. $622 \mathrm{c}$.

Чусь - Чусь Г. Н. Пословица недаром молвится. Более 5000 русских, украинских, английских и французских пословиц. М. : Либроком, 2020. $256 \mathrm{c}$.

\section{REFERENCES}

Arutiunova N.D., 1988. Tipy yazykovykh znacheniy: Otsenka. Sobytie. Fakt [Types of Linguistic Meanings: Evaluation. Event. Fact]. Moscow, Nauka Publ. 338 p.

Bayramova L.K., 2014. Poslovitsy v «Aksiologicheskom frazeologicheskom slovare russkogo yazyka: slovare tsennostey i antitsennostey» [Proverbs in "Axiological Dictionary of the Russian Idioms, the Dictionary of Values and Antivalues"]. Vestnik Novgorodskogo gosudarstvennogo universiteta [Vestnik of Novgorod State University], no. 77, pp. 10-12.

Grigoreva T.V., 2015. Aksiologicheskie osobennosti oppozitsii ‘sladkiy - gorkiy' v russkom yazyke [Axiological Features ofOpposition 'Sweet-Bitter' in Russian]. Vestnik Vyatskogo gosudarstvennogo gumanitarnogo universiteta, no. 8, pp. 87-93.

Zhukov V.P., 1991. Predisloviye. O slovare poslovits i pogovorok [Preface. On the Dictionary of Proverbs and Sayings]. Zhukov V.P. Slovar' russkikh poslovits i pogovorok [Dictionary of Russian Proverbs and Sayings]. Moscow, Russkiy yazyk Publ., pp. 9-21.

Lomakina O.V., Mokienko V.M., 2018. Tsennostnye konstanty rusinskoy paremiologii [Value Constants of the Rusin Paremiology (Compared with the Ukrainian and Russian Languages)]. Rusin, vol. 54, iss. 4, pp. 303-317. DOI: 10.17223/ 18572685/54/18.

Lomakina O.V., Mokienko V.M., 2019. Kontseptual'naya dikhotomiya «Bog» - «Dyavol»v rusinskoy frazeologii i paremiologii (na slavyanskom fone) [The Conceptual Dichotomy “God" - "Devil” in Russian Phraseology and Paroemiology (Against the Slavic Background)]. Vestnik Tomskogo 
gosudarstvennogo universiteta [Tomsk State University Journal], no. 447, pp. 55-62. DOI: 10.17223/15617793/447/7.

Marfina Zh.V., 2018. Tsennostno-aksiologicheskaya realizatsiya mikrokontseptov muzh, zhena $\mathrm{v}$ ukrainskoy i russkoy paremiynykh kartinakh mira [Value-Axiological Realisation of MicroConcepts Husband, Wife in the Ukraine and the Russian Paremiological World-Images]. Vestnik Kostromskogo gosudarstvennogo universiteta [Vestnik of Kostroma State University], vol. 24, no. 1, pp. 90-94.

Nikitina T.G., 2016. Sopostavitel'nyi slovar' poslovits i pogovorok kak lingvokulturologicheskiy i lingvokraevedcheskiy istochnik [The Comparative Dictionary of Proverbs and Phraseological Units As a Linguocultural and Regional Source]. Vestnik Pskovskogo gosudarstvennogo universiteta. Seriya: Sotsial'no-gumanitarnye nauki, no. 4, pp. 142-149.

Permyakov G.L., 1988. Osnovy strukturnoy paremiologii [Fundamentals of Structural Paremiology]. Moscow, Nauka Publ. 235 p.

Khlebda V., 2008. O chem dumaet russkiy indyuk, ili $\mathrm{Ob}$ ekvivalentakh poslovits $\mathrm{v}$ dvuyazychnom slovare [What Does the Russian Turkey Think About, or On the Equivalents of Proverbs in a Bilingual Dictionary]. Przeglad Rusycystyczny, no. 4 (124), pp. 90-104.

\section{DICTIONARIES}

Bayramova L.K. Aksiologicheskiy frazeologicheskiy slovar' russkogo yazyka: slovar' tsennostey $i$ antitsennostey [Axiological Phraseological Dictionary of the Russian Language: Dictionary of Values and Antivalues]. Kazan, Tsentr innovatsionnykh tekhnologiy, 2011. 359 p.

Grynblat M.Ya., ed. Prykazki i prymawki: u 2 kn. [Proverbs and Sayings. In 2 Books]. Minsk, Navuka i tjehnika Publ., 1976.

Dal V.I. Poslovitsy russkogo naroda: $v 2 t$. [Proverbs of the Russian People. In 2 Vols.]. Moscow, Khudozhestvennaya literatura Publ., 1984.

Ivanov E.E., Mokienko V.M. Russko-belorusskiy paremiologicheskiy slovar' [The RussianBelarusian Paremiological Dictionary]. Mogilev, Izd-vo MGU im. A.A. Kuleshova, 2007. 242 p.

Kotova M.Yu. Russko-slavyanskiy slovar' poslovits $s$ angliyskimi sootvetstviyami [The Russian-Slavonic Dictionary of Proverbs with English Equivalents]. Saint Petersburg, Izd-vo SPbGU, 2000. 360 p.

Mokienko V.M., Nikitina T.G., Nikolaeva E.K. Bolshoy slovar russkikh poslovits [A Large Dictionary of Russian Proverbs]. Moscow, Olma Media Grupp Publ., 2010. 1024 p.

Paziak M.M., ed. Prisliv'ia ta prikazki: $u 4 t$. [Proverbs and Sayings. In 4 Vols.]. Kiev, Naukova dumka Publ., 1989-2001, vol. 1, 1989. 479 p.; vol. 2, 1990. 524 p.; vol. 3, 1991. 440 p.; vol. 4, 2001. 392 p.

Sokolova M.I. Narodnaya mudrost. Poslovitsy $i$ pogovorki [Folk Wisdom. Proverbs and Sayings]. Novosibirsk, Ofset Publ., 2009. 622 p.

Chus' G.N. Poslovitsa nedarom molvitsya. Bolee 5000 russkikh, ukrainskikh, angliyskikh $i$ frantsuzskikh poslovits [The Proverb is not Without Reason. More than 5000 Russian, Ukrainian, English and French Proverbs]. Moscow, Librokom Publ., 2020. 256 p.

\section{Information About the Authors}

Valery M. Mokienko, Doctor of Sciences (Philology), Professor, Department of Slavic Philology, St. Petersburg University, Universitetskaya Emb., 7-9, 199034 Saint Petersburg, Russia, mokienko40@mail.ru, https://orcid.org/0000-0002-0264-0576

Tatiana G. Nikitina, Doctor of Sciences (Philology), Professor, Department of Educational Technologies, Pskov State University, Lenina Sq., 2, 180000 Pskov, Russia, cambala2007@yandex.ru, https://orcid.org/0000-0001-9006-9738

\section{Информация об авторах}

Валерий Михайлович Мокиенко, доктор филологических наук, профессор кафедры славянской филологии, Санкт-Петербургский государственный университет, Университетская наб., 7-9, 199034 г. Санкт-Петербург, Россия, mokienko40@mail.ru, https://orcid.org/0000-0002-0264-0576

Татьяна Геннадьевна Никитина, доктор филологических наук, профессор кафедры образовательных технологий, Псковский государственный университет, пл. Ленина, 2, 180000 г. Псков, Россия, cambala2007@yandex.ru, https://orcid.org/0000-0001-9006-9738 